\title{
Szignifikáns inverz kapcsolat a pajzsmirigy-stimuláló hormon (TSH) és a prosztataspecifikus antigén (PSA) vérszintjei között 40-75 éves korú férfiakban
}

\author{
Tóth Zoltán dr. ${ }^{1}$ - Gyarmati Béla dr. ${ }^{2}$ \\ Szabó Tamás $\mathrm{dr}^{3}{ }^{3}$ - Vásárhelyi Barna $\mathrm{dr}^{3}$ \\ ${ }^{1}$ Uzsoki Utcai Kórház, Urológiai Osztály, Budapest \\ ${ }^{2}$ Uzsoki Utcai Kórház, Szülészet-Nőgyógyászati Osztály, Budapest \\ ${ }^{3}$ Semmelweis Egyetem, Általános Orvostudományi Kar, Laboratóriumi Medicina Intézet, Budapest
}

\begin{abstract}
Bevezetés: Korábbi kísérletek és klinikai megfigyelések alapján a pajzsmirigyhormonok szerepet játszhatnak a prosztatarák kialakulásában.

Célkitüzés: Retrospektív adatelemzésünk során a pajzsmirigy-stimuláló hormon (TSH) és a prosztataspecifikus antigén (PSA) vérszintjei közötti kapcsolatot értékeltük a Semmelweis Egyetem Laboratóriumi Medicina Intézetében az elmúlt 12 évben mért TSH- és PSA-szintek alapján.

Módszer: A laboratóriumi informatikai rendszerből lekértük azon, 40 és 75 éves kor közötti férfi betegek TSH- és PSA-értékeit, akiknél a két mérés között legfeljebb 14 nap telt el $(\mathrm{n}=7279)$. A logaritmizált TSH- és PSA-szintek közti kapcsolatot többszörös regresszióval értékeltük, és a betegek életkorára korrigáltuk.

Eredmények: Az InPSA és lnTSH, valamint az lnPSA és az életkor között szignifikáns kapcsolatot találtunk $(\mathrm{r}=0,297$, illetve 0,472$)$. A hyperthyreoticus (TSH $<0,35 \mathrm{mU} / \mathrm{ml})(\mathrm{n}=405)$ és euthyreoticus (TSH $0,35-4,95 \mathrm{mU} / \mathrm{ml})(\mathrm{n}=$ 6698) betegek PSA-szintjei szignifikánsan különböztek, alacsonyabb TSH esetén magasabb volt a PSA-szint $(1,118$ $[0,639-2,338]$ vs. $0,920[0,508-1,826] \mathrm{ng} / \mathrm{ml}, \mathrm{p}<0,016)$. A regressziós elemzés alapján a TSH $10 \%$-os csökkenése esetén a vizsgált populációban $0,42 \%$-kal nő a PSA-szint. Ez azt jelenti, hogy ha egy betegnél a 2,0 $\mathrm{mU} / \mathrm{ml} \mathrm{TSH}$ szint $0,2 \mathrm{mU} / \mathrm{ml}$-re csökken, akkor a PSA-értéke $42 \%$-kal emelkedne.

Köpetkeztetés: Eredményeink arra utalnak, hogy a PSA-szint egészséges referenciatartománya hyperthyreoticus és euthyreoticus betegek között eltér. Javasolt, hogy a PSA klinikai vágóértékét a laboratóriumok a beteg pajzsmirigystatusa alapján módosítsák.
\end{abstract}

Orv Hetil. 2019; 160(35): 1376-1379.

Kulcsszavak: pajzsmirigyfunkció, TSH-szint, PSA-szint, referenciatartomány

An inverse significant association between thyroid stimulatory hormone (TSH) and prostate specific antigen (PSA) blood levels in males 40-75 years of age

Introduction: Recent experiments and clinical studies indicate the contribution of thyroid hormones to prostate pathology.

Aim: In our retrospective analyzis of university patient population, we evaluated the association between thyroid stimulatory hormone (TSH) and prostate specific antigen (PSA).

Method: From the Laboratory Information System we retrieved the data of male patients between 40 and 75 years of age who had been subjected to simultaneous TSH and PSA measurements during the last 12 years $(\mathrm{n}=7279)$. The association between $\log$ TSH and $\log$ PSA levels was tested with multiple regression analysis and adjusted for age. Results: Significant associations between $\log$ PSA and $\log \mathrm{TSH}$ and age $(\mathrm{r}=0.297$ and 0.472 , respectively $)$ were detected. PSA levels were higher in patients with TSH below $(\mathrm{n}=405)$ than in those with TSH within reference range $($ TSH $0,35-4,95 \mathrm{mU} / \mathrm{ml})(\mathrm{n}=6698)($ PSA level: 1.118 [0.639-2.338] vs. 0.920 [0.508-1.826] ng/ml, p<0.016). 
Based on estimates, a $10 \%$ decrease in TSH is associated with a $0.42 \%$ increase in PSA levels in our population. This corresponds to a $42 \%$ increase in PSA levels in the same patient if he would present with $0.2 \mathrm{mU} / \mathrm{ml}$ instead of 2.0 $\mathrm{mU} / \mathrm{ml} \mathrm{TSH}$.

Conclusion: The finding that hyperthyreosis might be associated with higher PSA levels indicates that PSA reference ranges would differ in hyperthyreotic and in euthyreotic patients. Probably the PSA clinical decision limits is also recommended to be modified according to the patient's thyroid status.

Keywords: thyroid function, TSH levels, PSA levels, reference range

Tóth Z, Gyarmati B, Szabó T, Vásárhelyi B. [An inverse significant association between thyroid stimulatory hormone (TSH) and prostate specific antigen (PSA) blood levels in males 40-75 years of age]. Orv Hetil. 2019; 160(35): 1376-1379.

(Beérkezett: 2018. október 28.; elfogadva: 2019. január 14.)

\section{Rövidítések}

ATBC $=($ Alpha-Tocopherol, Beta-Carotene Cancer $[$ Prevention Study]) Alfa-Tokoferol, Béta-Karotin (Rákmegelőző Vizsgálat $) ;$ GLIMS $=($ General Laboratory Information Management System) Általános Laborinformatikai Menedzsment Rendszer; $\ln =$ természetes alapú logaritmus; PSA = (prostate specific antigen) prosztataspecifikus antigén; T3 = trijód-tironin; T4 = tiroxin; $\mathrm{TSH}=($ thyroid stimulatory hormone $)$ pajzsmirigy-stimuláló hormon

A pajzsmirigyhormonok (elsősorban a trijód-tironin, T3) központi szerepet játszanak a sejtek anyagcseréjében, osztódásában. Egyes megfigyelések szerint a karcinogenezisben is szerepük lehet [1]. In vitro vizsgálatok során fokozták a prosztataráksejtek proliferációját [2]. Kimutatták, hogy a T3- és T4-hormonok a plazmamembrán- $\alpha \mathrm{v} \beta 3$-integrinhez kötődve egyes prokarcinogén útvonalakat aktiválva fokozzák a sejtproliferációt és az angiogenezist [3].

A pajzsmirigyhormonok humán prosztatarákban játszott szerepét két vizsgálat is kutatta. Ezek során a pajzsmirigyfunkció jellemzésére a TSH-szintet használták. (A TSH-szint elónye, hogy ép hypophysis-pajzsmirigy tengely esetén már a pajzsmirigyhormonszint kismértékú változása exponenciális TSH-szint-eltéréshez vezet; azaz a pajzsmirigy-diszfunkció mérésére a TSH messzemenókig alkalmas.) Egy keresztmetszeti vizsgálat kimutatta, hogy magasabb TSH-szintek esetén csökkent a prosztatarák veszélye [4]. A prospektív Alpha-Tocopherol, Beta-Carotene Cancer (ATBC) Prevention Study vizsgálat eredményei is azt igazolták, hogy a TSH-szintek alapján klinikai vagy szubklinikai hypothyreosis véd a prosztatarákkal szemben: azoknál a férfiaknál, akiknél a legmagasabb a TSH-szint, az euthyreoid férfiakhoz képest kisebb a prosztatarák kockázata [5].

A prosztataspecifikus antigén (PSA) a klinikai gyakorlatban az egyik legtöbbször kért tumormarker. A PSA egy, a kallikreincsaládba tartozó szerin-proteáz. Fiziológiás funkciója a szemenogelinnek, az ondóváladékban dominánsan jelen levő fehérjének a hasítása, ezáltal az ondó folyékonyságának biztosítása [6]. A PSA elsősorban a prosztatamirigy lumenében van jelen, kis (mintegy milliomod) mennyiségben azonban a szérumban is megjelenik. A PSA-szint meghatározása több országban a prosztatarákszúrési program része, mivel az életkor-specifikus referenciatartomány feletti értékek felhívhatják a figyelmet a prosztatarák lehetőségére, illetve az invazív diagnosztikus beavatkozás szükségességére [7].

Az eddig rendelkezésre álló klinikai megfigyelések kizárólag a TSH-szint alapján észlelt pajzsmirigy-diszfunkció és a diagnosztizált prosztatarák közötti összefüggésre vonatkoznak. Nincsenek adatok arról, hogy a pajzsmirigyfunkció és a PSA-szint között fennáll-e kapcsolat. Retrospektív adatelemzésünk során a Semmelweis Egyetem Laboratóriumi Medicina Intézetében az elmúlt 12 év során végzett vizsgálatok alapján az alap-PSA- és alapTSH-szintek közötti kapcsolatot elemeztük, és kimutattuk: a pajzsmirigyfunkció hatással lehet a PSA-szintekre is.

\section{Módszer}

A Semmelweis Egyetem Laboratóriumi Medicina Intézetében az elmúlt 12 év során végzett összes laboratóriumi vizsgálat eredményét lekértük az egyetemi laborinformatikai számítógépes GLIMS-rendszerból. Egy adatsor a kért vizsgálat nevét, a vizsgálat végzésének időpontját, eredményét, a referenciatartományt, a vizsgálatra használt eszköz elnevezését, a beteg központi azonosítóját, életkorát és nemét tartalmazza. Az így lekért közel 200 millió adatsor volt adatbázisunk alapja. Az adatbázis feldolgozása előtt a központi betegazonosítóból az irreverzibilis anonimizálási folyamat során egyedi azonosítót hoztunk létre. Az adatbázis fenti módon való létrehozását és értékelését a Semmelweis Egyetem Tudományos Kutatásetikai Bizottsága jóváhagyta.

Az adatbázisból leválogattuk azokat a férfiakat, akiknél TSH- és PSA-meghatározás 14 napon belül történt. Az így létrehozott szürt adatbázisban minden beteg egy alkalommal (a rendszerben rögzített legkorábbi dátum- 
mal) szerepelt. A TSH- és PSA-eredményeket egymás mellé rendelve összesen 7279 TSH-PSA adatpárt kaptunk.

A statisztikai elemzés során a TSH- és a PSA-szintek normalizálása érdekében ezek természetes alapú logaritmusával $(\ln )$ dolgoztunk (a méréshatár alatti PSA-értékek esetén egységesen $0,001 \mathrm{ng} / \mathrm{ml}$ értéket használtunk). Az lnPSA- és lnTSH-szintek közötti összefüggést többszörös regresszióval értékeltük.

Ezenkívül a betegeket a TSH-szint alapján hyperthyreoticus $(\mathrm{n}=405, \mathrm{TSH}<0,35 \mathrm{mU} / \mathrm{L})$ és euthyreoticus ( $\mathrm{n}=6698$, TSH 0,35-4,95 mU/L) csoportra osztottuk; a PSA-szinteket Wilcoxon-teszttel hasonlítottuk össze.

\section{Eredmények}

Eredményeinket az 1. táblázat összegezi. Az lnPSA-értékek és az életkor, illetve az lnPSA- és az lnTSH-értékek között szignifikáns kapcsolatot igazoltunk; 10\%-os TSH-

1. táblázat |A TSH- és a PSA-szintek kapcsolata 40 és 75 éves kor közötti férfiaknál a Semmelweis Egyetemen

\begin{tabular}{|c|c|}
\hline & $\mathrm{n}=7279$ \\
\hline Életkor, év (átlag, szórás) & $58,9 \pm 9,22$ \\
\hline PSA (medián, IQR) ng/ml & $0,931(0,511 ; 1,86)$ \\
\hline TSH (medián, IQR) mU/1 & $1,265(0,828 ; 1,89)$ \\
\hline \multicolumn{2}{|l|}{$\begin{array}{l}\text { A többszörös regressziós elemzés eredménye } \\
\text { (a PSA-szintre gyakorolt hatás) }\end{array}$} \\
\hline lnTSH (becslés (becslés hibája), p-érték) & $-0,042(0,014), 0,003$ \\
\hline Életkor (becslés (becslés hibája), p-érték) & $0,028(0,001),<0,001$ \\
\hline \multicolumn{2}{|l|}{ Az összefüggés r-értéke } \\
\hline $\ln \mathrm{TSH}$ & 0,297 \\
\hline Életkor & 0,472 \\
\hline
\end{tabular}

$\mathrm{IQR}=$ (independent quality review) független minőségi felülvizsgálat; PSA = prosztataspecifikus antigén; TSH = pajzsmirigy-stimuláló hormon

2. táblázat A csökkent TSH-szint hipotetikus hatása a mért PSA-szintekre egy betegen belül. Az elemzés alapján hyperthyreosisban az euthyreosisban meghatározott $4 \mathrm{ng} / \mathrm{ml}$ vágóértékhez közeli, illetve azt jóval meghaladó értékre emelkedhet a mért PSA-szin annál a betegnél, akinél euthyreoticus állapotban 2 , illetve 4 $\mathrm{ng} / \mathrm{ml}$ volt a PSA-szint

\begin{tabular}{lllll}
\hline $\begin{array}{l}\text { TSH-szint } \\
(\mathrm{mU} / \mathrm{ml})\end{array}$ & $\begin{array}{l}\text { TSH-eltérés a } \\
\text { hipotetikus 2 } \mathrm{mU} / \mathrm{ml} \\
\text { értékhez képest }\end{array}$ & \multicolumn{2}{l}{ Mért PSA-szint $(\mathrm{ng} / \mathrm{ml})$} \\
\hline 2 & 0 & 1 & 2 & 4 \\
1 & $4,20 \%$ & 1,04 & 2,08 & 4,16 \\
0,5 & $8,40 \%$ & 1,08 & 2,16 & 4,32 \\
0,2 & $42 \%$ & 1,42 & 2,84 & 5,68 \\
0,1 & $84 \%$ & 1,84 & 3,68 & 7,36 \\
\hline
\end{tabular}

PSA = prosztataspecifikus antigén; TSH = pajzsmirigy-stimuláló hormon szint-csökkenés esetén a PSA-szint 0,42\%-kal nő. Azt, hogy (elméletileg) a különböző TSH-értékekhez ugyanazon betegnél milyen PSA-szintek társulnának, a 2. táblázat demonstrálja.

A hyperthyreoticus és az euthyreoticus betegek közvetlen összehasonlításakor a PSA-szint a hyperthyreoticus betegeknél $(\mathrm{n}=405)$ szignifikánsan magasabb az euthyreoticusokhoz $(\mathrm{n}=6698)$ képest (medián, interkvartilis tartomány) (PSA-szint: 1,118 [0,639-2,338] vs. $0,920[0,508-1,826] \mathrm{ng} / \mathrm{ml}, \mathrm{p}<0,016)$.

\section{Megbeszélés}

Az irodalomban először találtunk bizonyítékot arra, hogy a PSA-szinteket az életkor mellett a pajzsmirigyfunkció szignifikánsan befolyásolja; hypothyreosisban inkább alacsony, míg hyperthyreosisban magasabb a PSA-szint. A hatás számszerűsíthető: 10\%-os TSH-szintváltozás esetén a PSA-szint $0,42 \%$-kal változik a TSHszintjével ellenkező irányba. Bár ez első pillantásra elenyészőnek túnik (a 0,42\%-os változás jóval a PSAmeghatározás 5-10\%-os mérési bizonytalansága alatt van), a TSH-szintek fluktuációjának, annak mértékének ismeretében mégsem ez a helyzet.

A TSH-szint egészséges referenciatartományát általánosan a 0,3 és $4,3 \mathrm{mU} / 1$ közötti értékek közötti tartományként adják meg. A TSH a pajzsmirigyhormonszint eltéréseire exponenciálisan reagál. Kismértékú pajzsmirigyhormonszint-emelkedés nagyfokú TSH-szint-csökkenést vált ki [8]. Ennek eredményeként például enyhe hyperthyreosis esetén a TSH 10-szeres, azaz 1000\%-os változást mutat az euthyreoticus állapothoz képest $(0,2$ vs. 2,0 mU/l). Ebben az esetben ehhez durván 40\%-os PSA-szint-emelkedés társulhat, ami különösen a határérték közeli PSA-szintek esetében zavaró lehet. Ez egyrészt felveti annak lehetőségét, hogy a döntően euthyreoticus populációban számított PSA-vágóértékeket hyperthyreoticus (illetve hypothyreoticus) populációkban talán módosítani kell; illetve, hogy kórosan magas PSA-értékek esetén érdemes a pajzsmirigymúködést ellenőrizni és nagyobb fenntartással kezelni. A mindennapi urológiai gyakorlatban különös jelentősége lehet az ismételt prosztatabiopszia indikációjának felállításakor, a felesleges invazív beavatkozások számának csökkentésével.

Retrospektív adatgyüjtésünk előnye, hogy statisztikailag nagyszámú adat értékelésére nyílt lehetőségünk. Az eredmények korlátja, hogy az adatbázisba került betegek az egészségügyi ellátás 3. szintjén (a Semmelweis Egyetem klinikáin) jelentkeztek; így a következtetések is csak erre a viszonylag speciális populációra vonatkoztathatók. Sajnos, az adatbázis nem tartalmazza a kíró diagnózist; azt, hogy a beteg urológiai betegségben/pajzsmirigybetegségben szenvedett-e, illetve, hogy kapott-e olyan gyógyszert, amely a PSA- és/vagy TSH-szintet befolyásolhatta. Bár az adatbázisban szereplő prosztatarákos, illetve endokrinológiai ambulanciákon gondozott bete- 
gek adatai valóban torzíthatják a kapcsolatot, ennek mértéke azonban a Laboratóriumi Medicina Intézet által ellátott közel félszáz klinika és az ott kezelt betegek nagy száma alapján korlátozott. Ráadásul az adatbázisban minden beteg csak egy alkalommal (az első ízben értékelt mintája révén) szerepelt. A kieső, szélsőséges adatok torzító hatása az adatok logaritmizálásával tovább csökken.

Az általános vélekedés szerint az emelkedett alap-PSAszint önmagában nem alkalmas a rák kimutatására. Hátterében a prosztatarák mellett egyéb tényező (például prostatitis, jóindulatú prosztatamegnagyobbodás) állhat. Összességében mégis elfogadott, hogy a magas alapPSA-szint a prosztata patológiás folyamatainak nagyobb kockázatára utal. (Ettől függetlenül még a mai magyar - európai viszonylatban nagy prosztatarák-prevalenciára utaló - epidemiológiai adatok [9] alapján sem szabad a PSA-szint alapján a prosztatarák diagnózisát kimondani.)

Retrospektív keresztmetszeti vizsgálatunk alapján nem lehet megmondani, hogy az alacsonyabb TSH-szintek mellett tendenciájukban kissé magasabb PSA-szintek hátterében milyen betegség áll, illetve, hogy az általunk értékelt alacsonyabb TSH-szintű betegek mekkora hányadánál áll fenn prosztatarák. Pontosan azt sem lehet tudni, hogy a TSH-szint-csökkenésben milyen szerepet játszik az alapbetegség, a gyógyszeres kezelés, a külső hőmérséklet hatása vagy akár a napszak. (Ráadásul munkánk során össz-TSH-szintet mértünk, az általunk használt teszt differenciált a hypophysis pars tuberalisában és a pars distalis részében termelt TSH-k között, amelyek biológiai jellemzői eltérőek lehetnek [10].) Ettől függetlenül megfigyelésünk összhangban van azzal a korábbi klinikai megfigyeléssel, hogy hyperthyreoticus személyeknél a prosztatarák gyakorisága az euthyreosisos személyekhez képest nagyobb [5], illetve, hogy a magas pajzsmirigyhormonszint fokozza a prosztatasejtek proliferációját [2].

\section{Következtetés}

A PSA-szintet az életkor mellett a pajzsmirigyfunkció is befolyásolhatja 40 és 75 éves kor között. Ennek hatása euthyreosisban elhanyagolható, súlyos hyperthyreosisban azonban klinikailag számottevő mértékû is lehet. Célszerú ezt a jelenséget figyelembe venni akkor, ha a laboratóriumban euthyreoticus populációban meghatározott PSA-referenciatartománynál magasabb a PSAszint egy hyperthyreoticus betegnél.

Anyagi támogatás: A munka elvégzését a GINOP-2.2.115-2017-00067. számú pályázat támogatta.
Szerzői munkamegosztás: T. Z.: A vizsgálat terve, az adatok értelmezése, a kézirat kritikus átolvasása és jóváhagyása. Gy. B.: Az adatok értelmezése, irodalomgyüjtés, a kézirat kritikus átolvasása és jóváhagyása. Sz. T.: Adatgyűjtés, adatelemzés, a kézirat kritikus átolvasása és jóváhagyása. V. B.: Adatelemzés, a kézirat összeállítása, jóváhagyása. A cikk végleges változatát valamennyi szerző elolvasta és jóváhagyta.

Érdekeltségek: A szerzőknek nincs olyan tényleges vagy lehetséges érdekeltsége, mely a kézirat beérkezését megelőző három évben hatással lehetett a cikk megírására.

\section{Köszönetnyilvánítás}

A statisztikai értékelésben nyújtott segítségért $d r$. Treszl Andrásnak (Hamburg, Németország) tartozunk köszönettel.

\section{Irodalom}

[1] Hercbergs A. The thyroid gland as an intrinsic biologic responsemodifier in advanced neoplasia - a novel paradigm. In Vivo 1996; 10: 245-247.

[2] Tsui KH, Hsieh WC, Lin MH, et al. Triiodothyronine modulates cell proliferation of human prostatic carcinoma cells by downregulation of the B-cell translocation gene 2. Prostate 2008; 68: 610-619.

[3] Pinto M, Soares P, Ribatti D. Thyroid hormone as a regulator of tumor induced angiogenesis. Cancer Lett. 2011; 301: 119-126.

[4] Hellevik AI, Asvold BO, Bjøro T, et al. Thyroid function and cancer risk: a prospective population study. Cancer Epidemiol Biomarkers Prev. 2009; 18: 570-574.

[5] Mondul AM, Weinstein SJ, Bosworth T, et al. Circulating thyroxine, thyroid-stimulating hormone, and hypothyroid status and the risk of prostate cancer. PLoS ONE 2012; 7: e47730.

[6] Balk SP, Ko YJ, Bubley GJ. Biology of prostate-specific antigen. J Clin Oncol. 2003; 21: 383-391.

[7] Pezaro C, Woo HH, Davis ID. Prostate cancer: measuring PSA. Intern Med J. 2014; 44: 433-440.

[8] Baloch Z, Carayon P, Conte-Devolx B, et al. Laboratory medicine practice guidelines. Laboratory support for the diagnosis and monitoring of thyroid disease. Thyroid 2003; 13: 3-126.

[9] Kásler M, Ottó S, Kenessey I. The current situation of cancer morbidity and mortality in the light of the National Cancer Registry. [A rákmorbiditás és -mortalitás jelenlegi helyzete a Nemzeti Rákregiszter tükrében.] Orv Hetil. 2017; 158: 84-89. [Hungarian]

[10] Drees JC, Stone JA, Reamer CR, et al. Falsely undetectable TSH in a cohort of South Asian euthyroid patients. J Clin Endocrinol Metab. 2014; 99: 1171-1179.

(Vásárhelyi Barna dr., Budapest, Nagyvárad tér 4., 1089 e-mail: vasarhelyi.barna@med.semmelweis-univ.hu) 